\title{
(t)
}

\section{ENSINO À DISTÂNCIA E SUAS IMPLICAÇÕES PARA A FORMAÇÃO DOS ASSISTENTES SOCIAIS: ỦMA REFLEXÃO DOS CURSOS EAD NO ESTADO DE PERNAMBUCO}

\author{
Distance Education and its implications for the \\ training of Social Assistants: a reflection of the EAD courses \\ in the State of Pernambuco
}

\section{Tatianne Amanda Bezerra da Silva' Josinês Barbosa Rabelo²}

\begin{abstract}
RESUMO
Este artigo tem como objetivo apresentar os elementos acerca da realidade da modalidade de ensino à distância no estado de Pernambuco, utilizando-se para tanto de documentos e dados disponibilizados pelo Conselho Regional de Serviço Social $-4^{\mathrm{a}}$ Região, recolhidos em seu processo de fiscalização do exercício profissional de Assistentes Sociais. A fim de enriquecer e aprofundar a pesquisa, utilizamos também a técnica de entrevista com 2 (duas) Assistentes Sociais que atuam no CRESS (PE), tendo em vista que são compostas de narrativas das situações vividas pelas profissionais nos processos de fiscalização realizados pelo referido conselho, complementando os dados coletados acerca do EaD e apresentando a incompatibilidade da educação à distância com a formação profissional em Serviço Social.
\end{abstract}

\section{PALAVRAS-CHAVE}

Ensino à distância. Formação profissional. Serviço Social.

\footnotetext{
Assistente Social. Mestranda em Educação Contemporânea pelo Programa de Pós-graduação em Educação Contemporânea da Universidade Federal de Pernambuco (UFPE, Recife, Brasil). Rua Dom Manoel de Medeiros, s/nº, Dois Irmãos, Recife (PE), CEP.: 52171-900. E-mail: <tatiannebezerra1@hotmail.com>. ${ }_{2}^{2}$ Assistente Social. Doutora em Desenvolvimento Urbano pela Universidade Federal de Pernambuco. Docente do curso de Serviço Social do Centro Universitário Joaquim Nabuco (UNINABUCO, Recife, Brasil). Av. Guararapes, $n^{\circ} 233$, Jardim Santo Antonio, Recife (PE), CEP.: 50010-460. E-mail: <josie.rabelo@gmaill.com>.
} 


\begin{abstract}
This article has a goal to introduce the elements about de reality of distance education mode in Pernambuco state, for that, we will use documents and data provided by social service regional council - 4th region collected in the exercise professional inspection process of social workers. In order to enrich and deppen the research, we use the technic of interview with 2 (two) social workers, they works in CRESS (PE), had in sight they are composed by narratives about some life situations lived by workers in the inspection process realized by relate council complementing the collected data about distance education and thus showing the incompatibility of distance education with professional formation in social work.
\end{abstract}

\title{
KEYWORDS
}

Distance education. Vocational training. Social work.

Submetido em: $22 / 6 / 2017$

A ceito em: 26/8/2017

\section{INTRODUÇÃO}

No Brasil, o Ensino à distância (EaD) surgiu em meio ao expressivo processo de ampliação e mercantilização do ensino superior, iniciado sobretudo no governo Fernando Henrique Cardoso (FHC) (19951998 e 1999-2002) e corroborado no decorrer da gestão petista de Luiz Inácio Lula da Silva (2003-2006 e 2007-2010) e Dilma Rousseff (2011-2014 e 2015-2016).

Trata-se de uma resposta à grande crise capitalista de 1970 e reordenamento neoliberal do Estado, conduzido pelos organismos internacionais e refletido na periferia do capitalismo em uma retração estatal para intervenções sociais e, consequentemente, intenso processo de privatização das políticas sociais (ANDERSON, 1995; CHAUÍ, 2001; PEREIRA, 2008; SOARES, 2009), com destaque para a educação, em particular a educação superior.

Como destaca Lima (2007), as políticas neoliberais vêm orientando um conjunto de reformas políticas e econômicas nos países periféricos, que incluem desde reestruturação da esfera produtiva, reordenamento do papel do Estado, até a formação de uma nova sociabilidade. Cumpre um papel fundamental, no contexto acima delineado, a utilização das Tecnologias da Informação e da Comunicação (TIC), enquanto mecanismos de mercantilização, ainda que esta utilização, por meio do EaD, apareça com o discurso de internacionalização e democratização do ensino. 
Nesse ínterim, utilizando-se do argumento de crise do Estado, o ensino superior é convertido em forte espaço de valorização do capital, além de ser utilizado para formação de um campo propício para consenso entre classes. Ou seja, no contexto de reação burguesa à crise capitalista, o ensino superior torna-se um espaço estratégico de valorização do capital e de reprodução da sociabilidade burguesa, especialmente mediante a expansão desmedida e sem critérios do EaD.

A expansão do ensino à distância, conforme destaca o Conselho Federal de Serviço Social (CFESS, 2011b), é fonte de grande preocupação, pois acaba por ferir a formação nas diversas áreas e níveis, configurando-se como uma educação aligeirada e sem consideração das reais necessidades do alunado. Contudo, tratando-se do curso de Serviço Social, a preocupação do Conselho ganha maiores proporções, tendo em vista o grande número de vagas do curso ofertadas nesta modalidade, o descumprimento das instituições de ensino à distância às Diretrizes Curriculares estabelecidas pela Associação Brasileira de Ensino e Pesquisa em Serviço Social (ABEPSS), a contradição referente ao seu direcionamento político acerca da educação enquanto direito universal, os prejuízos referentes às condições de trabalho e salariais dos Assistentes Sociais e, principalmente, às possíveis implicações de uma formação precarizada para os usuários de seus serviços. Além disto, ganha destaque a notícia publicada em um jornal do estado do Mato Grosso no ano de 2009, afirmando ser o Serviço Social um dos cursos à distância com irregularidades mais graves.

Nesse contexto, torna-se imprescindível àqueles que lutam por uma formação crítica e propositiva compreender tais mudanças, de modo a projetar estratégias de resistência. Em presença disso, pretendeu-se, através deste estudo, examinar o processo de mercantilização neoliberal dos dispositivos de formação profissional, considerando, fundamentalmente, as implicações do crescimento de instituições na modalidade à distância para o desenvolvimento de uma formação qualificada dos Assistentes Sociais, assim como contribuir para construção de um arsenal teórico crítico profissional acerca da temática. 
Para tanto, a investigação foi desenvolvida mediante abordagem qualitativa. A coleta de dados foi realizada pela pesquisa de campo, através das técnicas de entrevistas e pesquisa documental, especialmente os documentos elaborados pelo Conselho Federal de Serviço Social, Associação Brasileira de Ensino e Pesquisa em Serviço Social, bem como Ministério da Educação/Instituto Nacional de Estudos e Pesquisas Educacionais Anísio Teixeira (MEC/INEP), com as Sinopses Estatísticas da Educação Superior Brasileira.

A entrevista semiestruturada foi realizada com assistentes sociais membros do CRESS- $4^{\text {a }}$ Região, responsáveis pela fiscalização do exercício profissional. Faz-se mister destacar que a entrevista semiestruturada permite ao pesquisador uma relativa flexibilidade, na qual as questões não necessitam seguir necessariamente a ordem prevista no roteiro, ademais, a partir das respostas dos entrevistados, poderão ser formuladas novas questões, conforme postula Minayo (2010). As entrevistas são também compostas de narrativas das situações vividas que produziram importantes documentos sobre o fenômeno em estudo. É através dela que é possível compreender como se dá as implicações da modalidade de ensino à distância para uma formação qualificada em Serviço Social, isto é, por meio da entrevista foi possível analisar os dados do CRESS- $4^{a}$ Região construídos a partir dos procedimentos de fiscalização do exercício profissional e denúncias realizadas junto à entidade, tornando-os visíveis e apresentando, portanto, a incompatibilidade da educação à distância com a formação profissional em Serviço Social.

No processo de análise de dados, utilizou-se a técnica de análise de conteúdo, apontada por Setúbal (1999) como uma técnica de compreensão, interpretação e explicação das formas de comunicação (escrita, oral ou icônica), ultrapassando as evidências imediatas e buscando captar a estrutura das mensagens. Como unidades de análise, estabeleceu-se temáticas expressas pelos sujeitos entrevistados.

Nesse sentido, o corpus da pesquisa está constituído dos textos das falas dos sujeitos envolvidos na pesquisa, do estudo de documentos e bibliografias elaboradas acerca do tema. De modo a resguardar a identidade das entrevistadas, estas serão identificadas como A.S. 1 e A.S. 2. 


\section{EXPANSÃO DOS CURSOS DE SERVIÇO SOCIAL NO BRASIL}

Segundo Pereira (2008), embora no primeiro período de desertificação neoliberal brasileira, no governo Collor e Itamar (19901994), tinham sido criados apenas três novos cursos de Serviço Social, na gestão Fernando Henrique Cardoso (1995 a 2002), todavia, o processo de expansão e empresariamento da formação de Assistentes Sociais se mostram mais nítidos, com a criação de 49 novos cursos, o que significa um total 52 novas escolas entre 1990 e 2002.

Essas Instituições de Ensino Superior (IES) brasileiras estão organizadas de acordo com a natureza jurídica de suas mantenedoras, que podem ser públicas e privadas (com ou sem fins lucrativos). É importante ressaltar que as instituições registradas como 'públicas municipais' embora em grande parte cobre mensalidades e demais taxas, legalmente são registradas como 'fundações públicas do direito privado's e serão, portanto, consideradas como IESs públicas. Entretanto, ainda com esta consideração, como destaca Pereira (2008), há uma predominância absoluta de cursos de Serviço Social de natureza privada: $90,4 \%$ no período. Destes, a maioria (53,2\%) é particular no sentido estrito, o que demonstra o caráter mercantil dos cursos.

A autora evidencia que dos 52 cursos criados no período, 35 constituíram-se em IES não-universitárias (Faculdades, escolas/ institutos superiores, centros universitários), isto é, instituições não obrigadas à indissociabilidade entre ensino, pesquisa e extensão. Dos 17 inseridos em ambiente universitário, 14 eram de natureza privada. O que se percebe é, portanto, um amplo processo de mercantilização do ensino em Serviço Social no período supracitado.

No governo Lula, segundo o Censo da Educação Superior (BRASIL, 2010), de 2002 a 2009 houve um crescimento de 141,3\% no número de instituições de ensino superior brasileiras, passando de 1637 para a cifra de 2314 IES no país. Apesar de tanto o setor público quanto o privado apresentarem tendência de crescimento no número de instituições, as particulares continuam predominantes na educação superior brasileira, com $89,4 \%$ do número total de IES. Sendo responsáveis por $74,4 \%$ das matrículas no período. No que se refere à organização aca-

\footnotetext{
${ }^{3} \mathrm{O}$ que lhe possibilita receber recursos públicos e ao mesmo tempo isentar-se de normas que regem o direito público, como a cobrança de mensalidades, tendo em vista o princípio da gratuidade presente na legislação da educação superior pública.
} 
dêmica, faculdades continuam caracterizando a educação superior do país, com participação percentual de 85\% do total das IES em 2009.

Ainda de acordo com o Censo, o curso de Serviço Social encontra-se entre os dez maiores cursos de graduação em número de matrículas. No tocante à modalidade de ensino, o curso aparece na terceira posição, compreendendo $8,1 \%$ do total de matrículas de graduação à distância no Brasil, atrás apenas dos cursos de Pedagogia (34,2\%) e Administração (27,3\%). Nesse sentido, além da preocupação constante da categoria com a expansão do ensino em Serviço Social em instituições privadas, soma-se a preocupação com o alargamento desmesurado no número de cursos à distância em Serviço Social.

Os dados da Sinopse da Educação Superior 2009 ((INSTITUTO NACIONAL DE ESTUDOS E PESQUISAS EDUCACIONAIS ANÍSIO TEIXEIRA, 2009) mostram uma quantidade muito pequena de cursos à distância em Serviço Social, apenas 12 cursos (4\% do total), contra 307 (96\% do total) da modalidade presencial. Entretanto, esses poucos cursos EaD de Serviço Social abriram turmas em centenas de polos e telessalas de ensino à distância pelo país, passando a superar o número de vagas oferecidas pelos cursos presenciais, sendo, portanto, $24 \%$ das vagas ofertadas nos presenciais e $76 \%$ nos EaD.

Apesar do maior número de vagas ofertadas pelas instituições á distância, as IES presenciais encontram-se muito próximas das EaD no quantitativo de alunos matriculados, são 62.124 nas presenciais e 68.055 naquelas à distância. A sinopse destaca ainda a existência de vagas ociosas no curso de Serviço Social no ano de 2009, isto é, a existência de um maior número de vagas em relação à demanda pelas mesmas. Ainda de acordo com a sinopse do ano de 2009, 72\% das matrículas em Serviço Social foram em IES privadas e $28 \%$ em IES públicas, confirmando o forte processo de mercantilização do ensino no curso de Serviço Social.

De acordo com dados do Mapa do Ensino Superior no Brasil (SINDICATO DAS MANTENEDORAS DE ENSINO SUPERIOR, 2016), no período de governo Dilma Rouseff, em 2014, havia cerca de 7,8 milhões de alunos matriculados no ensino superior brasileiro. Destes, 6,5 milhões encontravam-se em cursos presenciais (83\%) e 1,3 milhão em cursos $\operatorname{EaD}(17 \%)$, sendo que $75 \%$ das matrículas estão reunidas na rede privada (5,9 milhões). Nas matrículas dos cursos à distância, 
de 2009 a 2014, houve um aumento de cerca de 60\%, sendo um crescimento de $80 \%$ na rede privada e uma queda de $19 \%$ na pública.

Portanto, nos últimos 6 anos, com o crescimento no número de cursos EaD de 60\% no Brasil, estes passaram de 849 cursos em 2009 e chegaram à cifra de 1.368 em 2014. Na rede privada, o aumento foi ainda maior, de 110\%, saindo de 449 cursos em 2000 para 941 em 2014.

Pedagogia continua liderando a procura dos cursos EaD no Brasil, com um total de aproximadamente 302 mil matrículas em 2014. Administração e Serviço Social também permanecem em segunda e terceira colocação entre os cursos à distância com maior procura no país, com 170.540 e 97.728 matrículas respectivamente. Analisando a realidade específica de Pernambuco, todavia, de acordo com as informações do Mapa do Ensino Superior no Brasil (SINDICATO DAS MANTENEDORAS DE ENSINO SUPERIOR, 2016), o curso de Serviço Social liderou a procura com cerca de 5,2 mil matrículas na modalidade à distância registradas no estado.

Estes dados apontam para uma realidade que preocupa a categoria. Foram inúmeras as lutas empreendidas pelo Serviço Social na busca pela garantia de uma formação crítica e propositava, entretanto, o contexto atual, isto é, contexto de formação majoritariamente privada e à distância em Serviço Social, parece apontar para novos desafios profissionais.

Não se conhece ainda muito sobre a realidade desses novos cursos. As pesquisas e proposições ainda se encontram em andamento, contudo, as tendências não são nada animadoras, conforme poderemos perceber a partir dos dados levantados sobre essa realidade no estado de Pernambuco.

\section{SERVIÇO SOCIAL E FORMAÇÃO PROFISSIONAL EM PERNAMBUCO: EXPANSÃO DA MODALIDADE DE ENSINO À DISTÂNCIA NO ESTADO}

O estado de Pernambuco está localizado na região nordeste do Brasil, possui 185 municípios e tem uma população de 8.796.448 habitantes, aproximadamente $4,6 \%$ da população brasileira, dos quais $80,2 \%$ moram em zonas urbanas, segundo a contagem populacional de 2010 realizada pelo Instituto Brasileiro de Geografia e Estatística (IBGE). A densidade demográfica estadual é de 89,62 
hab./km². A estimativa do Estado em 2016 é, segundo o mesmo instituto, de 9.410.336 habitantes.

Ainda segundo dados do Censo 2010 do IBGE, a composição étnica da população pernambucana é constituída por pardos (53,3\%), brancos (40,4\%), negros (4,9\%) e índios (0,5\%) (IBGE, 2010a).

Atualmente o estado conta com dezoito escolas de Serviço Social na modalidade presencial de ensino, quais sejam: Universidade Católica de Pernambuco (UNICAP), Universidade de Pernambuco (UPE), Universidade Federal de Pernambuco (UFPE), Universidade Salgado de Oliveira (UNIVERSO), Faculdade de Ciências Aplicadas e Sociais de Petrolina (FACAPE), Centro Universitário Estácio do Recife (ESTÁCIO RECIFE), Faculdade São Miguel (FSM), Faculdade escritor Osman da Costa Lins (FACOL), Faculdade de Ciências Contábeis de Recife(FACCOR), Centro Universitário dos Guararapes (UNIFG), Faculdade do Recife (FR), Centro Universitário Tabosa de Almeida (ASCES), Centro Universitário Maurício de Nassau (NASSAU Recife), Faculdades Integradas da Vitória de Santo Antão (FAINTVISA), Faculdade UNINABUCO Recife (UNINABUCO), Faculdade Joaquim Nabuco de Olinda (FJN), Faculdade Uninassau Caruaru (UNINASSAU Caruaru) e Faculdade de Ciências Humanas e Sociais de Serra Talhada (FACHUSST).

Além das escolas presenciais, o estado de Pernambuco conta com dezesseis escolas de Serviço Social na modalidade de ensino à distância, são elas:Universidade Estácio deSá(UNESA), Universidade Pitágoras (UNOPAR), Universidades Paulista (UNIP), Universidade Santo Amaro (UNISA), Universidade Salvador (UNIFACS), Universidade Católica Dom Bosco (UCDB), Universidade Tiradentes (UNIT), Universidade Luterana do Brasil (ULBRA), Universidade do Sul de Santa Catarina (UNISUL), Universidade Salgado de Oliveira (UNIVERSO), Universidade Anhaguera (UNIDERP), Universidade Potiguar (UNP), Centro Universitário Maringá (UNICESUMAR), Centro Universitário Estácio de Ribeirão Preto (ESTÁCIORP), Centro Universitário Planalto do Distrito Federal (UNIPLAN) e Centro Universitário Internacional (CUI) (BRASIL, C2017) 5 .

\footnotetext{
${ }^{4}$ Informações disponíveis no sítio eletrônico do IBGE (2010b).

5 Sobre instituições de ensino que ofertam o curso de Serviço Social em todo o Brasil acessar o portal e-MEC (BRASIL, C2017).
} 
Quadro 1 - Localização das instituições de ensino a distância que ofertam cursos de Serviço Social no estado de Pernambuco

\begin{tabular}{|c|c|c|}
\hline Unidade de Ensino & $\begin{array}{l}\text { Localização das Unidades } \\
\text { de Ensino que } \\
\text { desenvolvem o curso de } \\
\text { Serviço Social à distância } \\
\text { em Pernambuco }\end{array}$ & $\begin{array}{c}\text { Categoria } \\
\text { administrativa }\end{array}$ \\
\hline UNESA & Rio de Janeiro (RJ) & $\begin{array}{c}\text { Privada com fins } \\
\text { lucrativos }\end{array}$ \\
\hline UNOPAR & Londrina (PR) & $\begin{array}{c}\text { Privada com fins } \\
\text { lucrativos }\end{array}$ \\
\hline UNIP & São Paulo (SP) & $\begin{array}{l}\text { Privada sem fins } \\
\text { lucrativos }\end{array}$ \\
\hline UNISA & São Paulo (SP) & $\begin{array}{c}\text { Privada sem fins } \\
\text { lucrativos }\end{array}$ \\
\hline UNIFACS & Salvador (BA) & $\begin{array}{c}\text { Privada com fins } \\
\text { lucrativos }\end{array}$ \\
\hline UCDB & Campo Grande (MS) & $\begin{array}{c}\text { Privada sem fins } \\
\text { lucrativos }\end{array}$ \\
\hline UNIT & Aracaju (SE) & $\begin{array}{c}\text { Privada com fins } \\
\text { lucrativos }\end{array}$ \\
\hline ULBRA & Canoas (RS) & $\begin{array}{c}\text { Privada sem fins } \\
\text { lucrativos }\end{array}$ \\
\hline UNISUL & Tubarão (SC) & $\begin{array}{c}\text { Privada sem fins } \\
\text { lucrativos }\end{array}$ \\
\hline UNIVERSO & São Gonçalo (RS) & $\begin{array}{l}\text { Privada sem fins } \\
\text { lucrativos }\end{array}$ \\
\hline UNIDERP & Campo Grande (MS) & $\begin{array}{c}\text { Privada com fins } \\
\text { lucrativos }\end{array}$ \\
\hline UNP & Natal (RN) & $\begin{array}{c}\text { Privada com fins } \\
\text { lucrativos }\end{array}$ \\
\hline UNICESUMAR & Maringá (PR) & $\begin{array}{c}\text { Privada com fins } \\
\text { lucrativos }\end{array}$ \\
\hline ESTÁCIORP & Ribeirão Preto (SP) & $\begin{array}{c}\text { Privada com fins } \\
\text { lucrativos }\end{array}$ \\
\hline UNIPLAN & Brasília (DF) & $\begin{array}{c}\text { Privada sem fins } \\
\text { lucrativos }\end{array}$ \\
\hline CUI & Curitiba (PR) & $\begin{array}{l}\text { Privada com fins } \\
\text { lucrativos }\end{array}$ \\
\hline
\end{tabular}

Fonte: Brasil (c2017).

Nota: Quadro sistematizado pelas autoras com base nos dados disponibilizadas no sítio eletrônico do E-mec/MEC). 
Podemos observar, no quadro acima, que todas as unidades de ensino que desenvolvem o curso de Serviço Social à distância em Pernambuco não possuem sede no estado. Percebe-se também que todas elas são de iniciativa privada. Sendo assim, Pernambuco conta atualmente com apenas quatro instituições de ensino públicas. Destas, duas são de natureza municipal, uma pública estadual e uma pública federal ${ }^{6}$.

Vale ressaltar que, embora a UNIP, UNISA, UCDB, ULBRA, UNISUL, UNIVERSO e UNIPLAN se declarem instituições sem fins lucrativos, funcionam como verdadeiras empresas educacionais, com um número exorbitante de polos distribuídos pelo país e sem um forte compromisso com a qualidade da formação ofertada.

Os cursos de Serviço Social à distância começam a ser ofertados em Pernambuco no ano de 2007, pela UNIDERP, sendo esta seguida pelas demais unidades de ensino.

De acordo com a pesquisa realizada, a unidade de ensino que desenvolve o curso de Serviço Social há mais tempo é a Universidade Federal de Pernambuco, onde o referido curso foi iniciado em 06 de junho de 1940, seguida pela Universidade Católica de Pernambuco, que teve o início de funcionamento do curso no dia 26 de fevereiro de 1973, conforme a lógica histórica de criação de escolas de Serviço Social brasileiras por instituições religiosas (IAMAMOTO; CARVALHO, 2011).

Em todas as demais instituições (tanto presenciais, quanto à distância) o curso de Serviço Social passou a ser ofertado a partir dos anos 2000, mais especificamente, a partir do ano de 2007 , com um perfil que se enquadra na prestação privada da política educacional, isto é, as escolas de Serviço Social passam a ser implementadas no estado de Pernambuco no contexto de contrarreforma da educação, onde o Estado retrai cada vez mais sua intervenção e, em contrapartida, transfere a responsabilidade da prestação de educação superior para o setor privado.

${ }^{6}$ São elas: Faculdade de Ciências Aplicadas e Sociais de Petrolina (FACAPE), Faculdade de Ciências Humanas e Sociais de Serra Talhada (FACHUSST), Universidade de Pernambuco (UPE) e Universidade Federal de Pernambuco (UFPE), respectivamente. 
Outro elemento que chamou atenção, durante o processo de coleta de dados, refere-se ao fato da grande maioria dos cursos EaD em Pernambuco encontrar-se inserida em instituições universitárias, sendo apenas duas das instituições de ensino centros universitários. Ao levarmos em consideração as denúncias realizadas junto ao conjunto CFESS/CRESS, estas instituições não vêm oferendo em seus cursos as condições necessárias para que seus alunos desenvolvam atividade de pesquisa e extensão, essenciais para uma formação crítica e de qualidade, como estabelecida nas Diretrizes Curriculares para os cursos de Serviço Social, muito menos numa perspectiva compatível à lógica de universidade.

Ao examinarmos suas respectivas cargas horárias, percebemos que todas possuem uma carga horária de pelo menos 3000 horas, em conformidade com as Diretrizes Curriculares da ABEPSS e do MEC. A diferença, contudo, se expressa no regime adotado pelas instituições. Embora a maior parte delas mantenha 0 regime semestral, com 8 semestres e, portanto 4 anos de curso, temos as seguintes particularidades: CUI aponta para um regime quadrimestral, de 12 quadrimestres, o que representaria apenas 3 anos de curso; UNICESUMAR utiliza regime anual, somando 4 anos de curso; a UNIDERP e a UNIPLAN utilizam regime semestral, mas adotam apenas 7 semestres; a UNIVERSO oferta um regime trimestral, com 16 trimestres no total; e a UNIP indica que seus cursos, apesar de adotarem regime semestral, possuem apenas 4 semestres, ou seja, a instituição aponta para apenas dois anos de curso.

Outro dado identificado pela pesquisa refere-se ao número de polos de EaD em Pernambuco e a quantidade de municípios que atualmente contam com ao menos uma turma de Serviço Social. No quadro a seguir, podemos visualizar os municípios pernambucanos onde foram instalados polos das instituições de ensino à distância.

Quadro 2 - Número de polos e localização das unidades de ensino que ofertam o curso de Serviço Social à distância em Pernambuco 


\begin{tabular}{|c|c|}
\hline $\begin{array}{l}\text { Unidade de } \\
\text { Ensino }\end{array}$ & Número de polos em Pernambuco e localização \\
\hline UNESA & $\begin{array}{l}1 \text { no município de Carpina, } 1 \text { no município de Caruaru, } 1 \text { no município de } \\
\text { Jaboatão dos Guararapes e } 2 \text { no município de Recife. }\end{array}$ \\
\hline UNOPAR & $\begin{array}{l}2 \text { no município de Araripina, } 2 \text { no município de Arcoverde, } 2 \text { no município de } \\
\text { Cabo de Santo Agostinho, } 2 \text { no município de Carpina, } 1 \text { no município de } \\
\text { Caruaru, } 2 \text { no município de Garanhuns, } 2 \text { no município de Gravatá, } 1 \text { no } \\
\text { município de Palmares, } 2 \text { no município de Paulista, } 1 \text { no município de } \\
\text { Pesqueira, } 2 \text { no município de Petrolina, } 3 \text { no município de Recife, } 2 \text { no } \\
\text { município de Salgueiro, } 2 \text { no município de Santa Cruz do Capibaribe. }\end{array}$ \\
\hline UNIP & $\begin{array}{l}1 \text { no município de Afogados da Ingazeira, } 1 \text { no município de Araripina, } 1 \text { no } \\
\text { município de Arcoverde, } 1 \text { no município de Belém de São Francisco, } 1 \text { no } \\
\text { município de Cabo de Santo Agostinho, } 1 \text { no município de Caruaru, } 1 \text { no } \\
\text { município de Garanhuns, } 1 \text { no município de Goiana, } 1 \text { no município de Gravatá, } \\
1 \text { no município de Jaboatão dos Guararapes, } 1 \text { no município de Olinda, } 1 \text { no } \\
\text { município de Paulista, } 1 \text { no município de Petrolina, } 3 \text { no município de Recife, } 1 \\
\text { no município de Salgueiro, } 1 \text { no município de Serra Talhada, } 1 \text { no município de } \\
\text { Vitória de Santo Antão. }\end{array}$ \\
\hline UNISA & 1 na ilha de Fernando de Noronha. \\
\hline UNIFACS & 1 no município de Jaboatão dos Guararapes e 1 no município de Recife. \\
\hline UCDB & 1 no município de Recife \\
\hline UNIT & $\begin{array}{l}1 \text { no município de Caruaru, } 1 \text { no município de Garanhuns, } 1 \text { no município de } \\
\text { Petrolina e } 1 \text { no município de Recife. }\end{array}$ \\
\hline ULBRA & $\begin{array}{l}1 \text { no município de Belo Jardim, } 1 \text { no município de Garanhuns, } 1 \text { no município de } \\
\text { Lagoa Grande e } 1 \text { no município de Santa Maria da Boa Vista. }\end{array}$ \\
\hline UNISUL & 1 no município de Petrolina e 1 no município de Recife. \\
\hline UNIVERSO & $\begin{array}{l}1 \text { no município de Recife, } 1 \text { no município de São José do Egito e } 1 \text { no município } \\
\text { de Caruaru. }\end{array}$ \\
\hline UNIDERP & $\begin{array}{l}1 \text { no município de Cabo de Santo Agostinho, } 1 \text { no município de Araripina, } 1 \text { no } \\
\text { município de Abreu e Lima, } 2 \text { no município de Caruaru, } 1 \text { no município de } \\
\text { Garanhuns, } 2 \text { no município de Igarassu, } 1 \text { no município de Ipojuca, } 1 \text { no } \\
\text { município de Jaboatão dos Guararapes, } 2 \text { no município de Olinda, } 1 \text { no } \\
\text { município de Petrolina, } 3 \text { no município de Recife, } 2 \text { no município de Serra } \\
\text { Talhada. }\end{array}$ \\
\hline UNP & 1 no município de Recife. \\
\hline UNICESUMAR & $\begin{array}{l}1 \text { no município de Caruaru, } 1 \text { no município de Jaboatão do Guararapes, } 2 \text { no } \\
\text { município de Olinda, } 1 \text { no município de Petrolina, } 2 \text { no município de Recife, } 1 \\
\text { no município de Santa Cruz do Capibaribe e } 1 \text { no município de Serra Talhada. }\end{array}$ \\
\hline ESTÁCIORP & 1 no município de Garanhuns \\
\hline UNIPLAN & $\begin{array}{l}1 \text { no município de Jaboatão dos Guararapes, } 1 \text { no município de Olinda e } 1 \text { no } \\
\text { município de Recife. }\end{array}$ \\
\hline CUI & $\begin{array}{l}1 \text { no município de Caruaru, } 1 \text { no município de Ipojuca, } 1 \text { no município de Olinda, } \\
1 \text { no município de Petrolina, } 2 \text { no município de Recife e } 1 \text { no município de } \\
\text { Salgueiro. }\end{array}$ \\
\hline
\end{tabular}

Fonte: Brasil (c2017).

Nota: Quadro sistematizado pelas autoras com base nos dados disponibilizados no sítio eletrônico do E-mec/MEC (BRASIL, c2017)

A análise do quadro 2 aponta que dos 185 municípios pernambucanos, 29 possuem ao menos um polo com oferta do curso de Serviço Social, isto é, o estado conta atualmente com 106 polos de ensino a distância distribuídos por seu território, embora concentrados majoritariamente nas proximidades da capital do estado. Esse dado 
é extremamente preocupante, principalmente quando se leva em consideração que a maioria destas cidades é de pequeno e médio porte, deparando-se com dificuldades até mesmo para encontrar campos de estágio para os estudantes.

Estes, apesar da grande oferta de vagas, nem sempre possuem as condições adequadas de funcionamento. Conforme prevê o documento Referênciais de qualidade para educação superior á distância, "[...] o polo de apoio presencial é a unidade operacional para desenvolvimento descentralizado de atividades pedagógicas e administrativas relativas aos cursos e programas ofertados à distância" (BRASIL, 2007, p. 25). Trata-se, pois, de uma unidade operacional que, além de funcionar como ponto de referência para o estudante, deve proporcionar uma estrutura essencial para o desenvolvimento de suas atividades, isto é,

A primeira, que tem a sua origem em algumas [...] os polos de apoio presencial devem contar com estruturas essenciais, cuja finalidade é assegurar a qualidade dos conteúdos ofertados por meio da disponibilização aos estudantes de material para pesquisa e recursos didáticos para aulas práticas e de laboratório, em função da área de conhecimento abrangida pelos cursos. Desse modo, torna-se fundamental a disponibilidade de biblioteca, laboratório de informática com acesso a Internet de banda larga, sala para secretaria, laboratórios de ensino (quando aplicado), salas para tutorias, salas para exames presenciais [...] (BRASIL, 2007, p. 26).

Contudo, apesar dos referenciais estabelecidos pelo Ministério de Educação (MEC), de acordo com informações das Assistentes Sociais membros do CRESS-4 ${ }^{a}$ Região, são frequentes nos processos de fiscalização do conselho, a identificação de polos EaD que não disponibilizam a estrutura física necessária estabelecida pelo ministério.

Vale destacar que, quando se refere à localização e número de polos EaD que oferecem o curso de Serviço Social, não se considera o quantitativo de telessalas distribuídas por suas imediações. Estas possuem uma identificação e quantificação ainda mais difícil do que os primeiros, tendo em vista que não há nenhuma informação disponibilizada no sítio eletrônico do MEC referente a este quesito. 
Portanto, quando se considera o número exorbitante de unidades de ensino descentralizadas, isto é, dos polos EaD com turmas de Serviço Social. Ainda assim, não se tem uma visão real da expansão do ensino nessa modalidade.

Todavia, apesar desta limitação, de modo a permitir um melhor entendimento da distribuição e densidade do número de polos EaD no estado de Pernambuco, apresentamos a seguir a distribuição geográfica dos municípios que possuem turmas de Serviço Social à distância. É possível identificar os municípios a partir do destaque em estrela.

Figura 1 - Distribuição geográfica dos municípios que possuem ao menos um polo com turma de Serviço Social à distância no estado de Pernambuco.

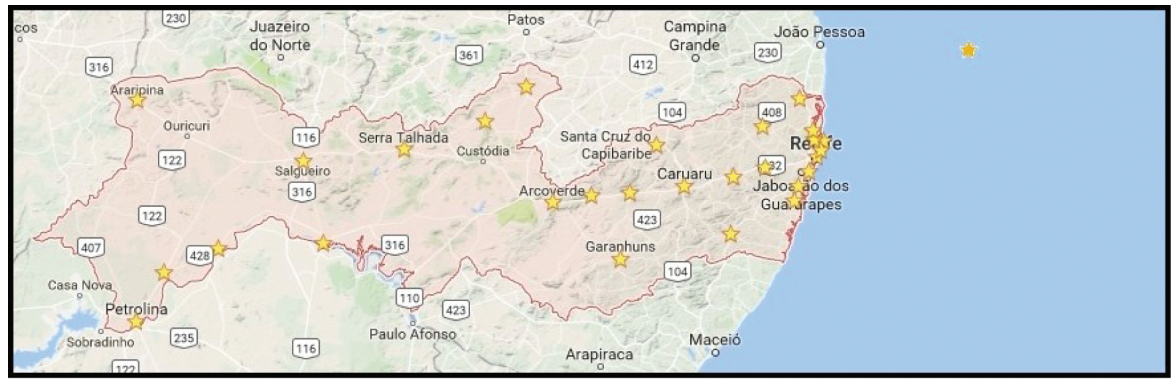

Fonte: Adaptado pelas autoras com base nos dados disponibilizados no sítio eletrônico do GoogleMaps (c2017).

Como ressaltado anteriormente, apesar de algumas unidades se encontrarem em municípios dispersos, a grande parte concentrase na mesma região, próximo ao litoral e capital do Estado. Ao compararmos a distribuição geográfica das localidades que possuem turmas de EaD em Serviço Social com aquelas em que estes cursos são presenciais, a diferença é latente. São apenas 7 municípios Pernambucanos que contam com turmas presenciais de Serviço Social, quais sejam: Recife, Petrolina, Vitória de Santo Antão, Olinda, Jaboatão dos Guararapes, Serra Talhada e Caruaru. Em todos esses municípios mencionados, existem também turmas EaD em Serviço Social.

Figura 2 - Distribuição geográfica dos municípios que possuem turmas de Serviço Social presenciais no estado de Pernambuco. 


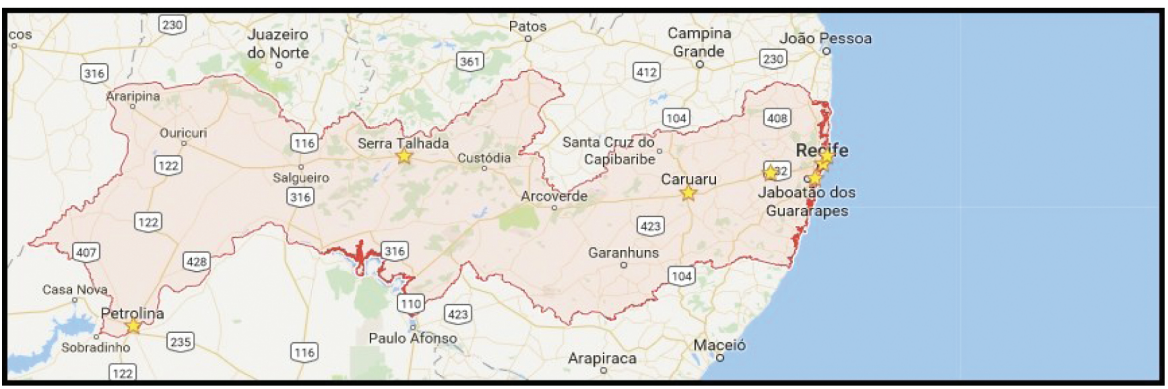

Fonte: Adaptado pelas autoras com base nos dados disponibilizados no sítio eletrônico do GoogleMaps (c2017).

Se levarmos em consideração o alcance e possibilidades de acesso do alunado a essas unidades de ensino presenciais, sem dúvidas, perceberemos limitações, tendo em vista que se encontram bastante dispersas e concentram-se em apenas 7 municípios. Contudo, é importante considerarmos o significado desse processo de interiorização e expansão das EaD's pelo Estado, haja vista que, para além da noção de oportunidade de acesso ao ensino superior de camadas nunca antes contempladas, é necessária e urgente a reflexão acerca do modo e qualidade com que este acesso vem sendo garantido.

Ao que tudo indica, trata-se de um brutal processo de mercantilização da formação profissional em Serviço Social que atende aos interesses do capital de expansão dos mercados e produção em massa de profissionais acríticos e consonantes aos ideais burgueses. $\mathrm{O}$ EaD, neste contexto, configura-se como via excepcionalmente lucrativa para as empresas educacionais, principalmente aqueles relativos à área de Humanidades, como é o caso do Serviço Social, em decorrência dos baixos custos de investimento e alto retorno financeiro, fundamentado na disponibilização de um grande número de vagas (PEREIRA, 2008; 2009).

Um levantamento realizado junto ao CRESS-4 ${ }^{\text {a }}$ Região é sintomático dessa realidade expansiva. Segundo informações do referido Conselho, no ano de 2011, foram registrados em Pernambuco 358 novos Assistentes Sociais, dos quais 156 eram oriundos do EaD e 202 das demais instituições; em 2012, esse número subiu para 485 novos inscritos, sendo 343 oriundos do EaD e 142 das demais instituições; no ano de 2013, o total de bacharéis inscritos no referido conselho elevou-se ainda mais, somando-se um total de 740 novos inscritos, sendo 481 oriundos do EaD e 259 das demais instituições. 
As instituições EaD, nesse sentido, apesar de se constituírem em menor número, como é o caso de Pernambuco, apenas 16 instituições de ensino ofertantes do curso de Serviço Social na modalidade à distância em detrimento de 18 instituições presenciais com oferta do curso, seu número de polos e vagas autorizadas excedem as das presenciais, conforme podemos vislumbrar na ilustração 5:

Quadro 3 - Número de vagas do curso de Serviço Social autorizadas pelo MEC a serem ofertadas pelas unidades de ensino anualmente

\begin{tabular}{|c|c|}
\hline Unidade de Ensino & $\begin{array}{l}\text { Número de vagas anuais } \\
\text { autorizadas }\end{array}$ \\
\hline \multicolumn{2}{|c|}{ Presencial } \\
\hline UNICAP & 40 \\
\hline UPE & 40 \\
\hline UFPE & 120 \\
\hline UNIVERSO & 600 \\
\hline FACAPE & 100 \\
\hline ESTÁCIO RECIFE & 300 \\
\hline FSM & 150 \\
\hline FACOL & 200 \\
\hline FACCOR & 80 \\
\hline UNIFG & 200 \\
\hline FR & 100 \\
\hline ASCES & 100 \\
\hline NASSAU Recife & 240 \\
\hline FAINTVISA & 100 \\
\hline UNINABUCO & 240 \\
\hline FJN & 240 \\
\hline UNINASSAU Caruaru & 240 \\
\hline FACHUSST & 100 \\
\hline \multicolumn{2}{|c|}{ Distância } \\
\hline UNESA & 5050 \\
\hline UNOPAR & 21150 \\
\hline UNIP & 47880 \\
\hline UNISA & 2300 \\
\hline UNIFACS & 1100 \\
\hline UCDB & 200 \\
\hline UNIT & 110 \\
\hline ULBRA & 400 \\
\hline UNISUL & 200 \\
\hline UNIVERSO & 2000 \\
\hline UNIDERP & 16800 \\
\hline UNP & 249 \\
\hline UNICESUMAR & 2000 \\
\hline ESTÁCIORP & 5000 \\
\hline UNIPLAN & 4260 \\
\hline CUI & 3000 \\
\hline
\end{tabular}

Fonte: Brasil (c2017).

Nota: Quadro sistematizado pelas autoras com base nos dados disponibilizadas no sítio eletrônico do E-mec/MEC. Acesso em: 22 jun. 2017. 
É relevante ressaltar que as vagas autorizadas para as IES presenciais são utilizadas tão somente em uma instituição, isto é, em sua sede, em contrapartida, as IES na modalidade EaD, que contam com este número de vagas, devem utilizá-las em todo território nacional, ou seja, devem subdividi-las por seus mais diversos polos e telessalas distribuídas pelo país. Este é um dos motivos por que contam com altos números de vagas. Contudo, ainda assim, ao analisarmos os dados, podemos verificar o número exorbitante de novas vagas para cursos de Serviço Social em Pernambuco através das EaD's, refletindo o processo de mercantilização e massificação de diplomas.

Conforme destaca o documento do MEC sobre os referenciais de qualidade para educação superior à distância (2007), um projeto de curso superior não presencial precisa de forte compromisso institucional em termos de garantir o processo de formação que contemple a dimensão técnico-científica para o mundo do trabalho e a dimensão política para a formação do cidadão, isto é, um compromisso da instituição de ensino para com o serviço educacional prestado, de modo que esse seja garantido com qualidade.

Entretanto, a partir da análise dos dados colhidos e apresentados pelo CFESS Manifesta (2011a), percebe-se o descompromisso das Instituições de Ensino com a formação profissional de qualidade e a falta de controle e acompanhamento sistemático da expansão e prestação de serviços dessas instituições por parte do Ministério da Educação. O processo de credenciamento junto ao MEC tem ocorrido de maneira superficial, não estabelecendo condicionalidades para a avaliação estatal in loco com vista à confirmação das informações prestadas pelas instituiçõos proponentes, como nos cursos de graduação presenciais.

Tendo em vista os aspectos supracitados, passemos agora aos elementos trazidos pelo CRESS-4 ${ }^{a}$ Região em entrevista, revelados a partir dos procedimentos de fiscalização do exercício profissional e denúncias realizadas junto à entidade, que torna visível a dinâmica acima analisada, apresentando, portanto, a incompatibilidade da educação à distância com a formação profissional em Serviço Social. 


\section{a) Projeto pedagógico em consonância com as Diretrizes Curriculares da ABEPSS}

Essa foi, de longe, a temática mais apresentada pelas Assistentes Sociais do CRESS- $4^{\text {a }}$ Região em entrevista. Conforme destacam, o ensino à distância é inegavelmente incompatível com a formação em Serviço Social, justamente pela veemente luta da categoria em prol do cumprimento da proposta curricular aprovada pela ABEPSS, que defende a necessária existência do tripé ensino, pesquisa e extensão para uma formação qualificada dos Assistentes Sociais, que a EaD não oferece.

Segundo as profissionais, o EaD tem uma dimensão bem diferenciada das Diretrizes Curriculares da área. E, embora se dê maior destaque a esta modalidade, a questão da luta por uma educação de qualidade do conjunto CFESS/CRESS é em todos, não é só no $E a D$, pois também são encontradas algumas dificuldades nas instituições presenciais privadas e nas presenciais públicas. A questão, contudo, é que, nos cursos à distância, as problemáticas são mais flagrantes e frequentes. Nos termos da A.S. 2:

Eu tenho uma colega que é formada em uma presencial privada. Ela passou no mestrado na Universidade Federal de Pernambuco e eu achei bastante interessante a posição dela, do que ela precisou para poder conseguir, em termos de formação. Ela teve que correr atrás de preencher algumas lacunas. Isso porque se formou em uma faculdade presencial, que não é de Pernambuco, mas é de renome. [...] Ela disse que nunca leu nem o capital, não chegou nem perto e que teve que ler. A dificuldade que ela teve de entender algumas coisas, de ir e voltar várias vezes. Não que a gente que foi da Federal, [... ] a gente não tenha 'nossas' dificuldades. Dia desses, eu estava lendo um livro que 'tive que ler' umas três vezes para poder entender o que o autor quer me dizer. Mas [...] no EaD a lacuna é densa.

A grande diferença é, portanto, que na formação presencial os alunos possuem maior oportunidade de fazer pesquisa, participar de uma monitoria, de participar de uma extensão e de ter contato com outros cursos. Isto acontece porque nas instituições presenciais, em grande parte, a proposta curricular encontra-se 
em consonância com as Diretrizes da ABEPSS. Por tratar-se de um currículo bastante amplo, que perpassa a área da economia, a área da psicologia, da sociologia, etc.. É preciso que a instituição de ensino possibilite o acesso do alunado a projetos de pesquisa e compartilhamento de discussões com outros cursos, de modo que o discente desenvolva uma capacidade de análise crítica da realidade social e da própria profissão, o que o EaD não vem oferecendo. "Ele vai fazer uma análise pelo computador, ele vai discutir com o computador" (A.S. 2).

Eu fui formada em uma universidade federal né? A Federal da Paraíba. Tive oportunidade de trabalhar como aluna bolsista. Então tive que trabalhar com a pesquisa, além de ter contato com alunos de outros cursos, o que contribui bastante para nossa formação, mas o aluno a distância não tem acesso, ele tem contato com o computador, com exceção de um dia né? Que é a vídeo aula, que é presencial, ele tem contato com os seus colegas de turma e que a pessoa responsável é chamada de tutor de sala, não é uma profissional preparada para dar aula, porque ela não fez mestrado, não fez doutorado. Ela é Assistente Social graduada né? (A.S. 2).

Segundo a Assistente Social supracitada, este processo acarreta uma série de fatores, com destaque para imagem construída da profissão, construída historicamente e por meio de muita luta, de modo a romper com o passado conservador tão caro ao Serviço Social. Imagem construída por todos os Assistentes Sociais que nos antecederam e por todos aqueles que ainda continuam na luta pela valorização e respeito profissional, mas que vem sendo fortemente atacada pela ofensiva neoliberal, refletindo-se na formação de um amplo contingente de intelectuais colaboracionistas, uma formação técnica, adaptada aos interesses capitalistas. "Não é um profissional formado dentro de uma postura crítica e propositiva, é dentro de uma postura técnica, imediatista e pragmática, como o capital quer" (A.S. 2).

Do ponto de vista de Pereira (2008), esta é uma realidade bastante desanimadora para a profissão, caracterizada por uma formação aligeirada, perpassada pela lógica mercantil, com turmas lotadas, professores horistas em condições precárias de trabalho e sem 
condições de realização da valiosa dimensão da pesquisa. "Tais condições esvaziam a possibilidade de formação de profissionais críticos, capazes de desvelar a realidade, sob a ótica dos interesses da classe trabalhadora. Pois como apreender uma teoria social crítica nas condições desastrosas de formação apontadas?" (PEREIRA, 2008, p. 195).

Trata-se de um processo flagrante de precarização da formação. Nítido até mesmo pela própria denominação do curso por parte desses alunos, que, como destacam as Assistentes Sociais, é chamado de 'curso de assistência social'. Este é um problema que se refere ao ensino que antecede o nível superior, isto é, vem da própria formação básica. "São pessoas que têm dificuldade até no seu falar, muitas vezes, fez um supletivo e fez um EaD" (A.S 2). Assim, a dificuldade enfrentada por estes alunos é enorme e, sem um acompanhamento necessário, reflete-se na colocação desse indivíduo enquanto profissional, posicionamento enquanto categoria, nas discussões com outras áreas, de atender a demanda que lhe é posta de uma forma que considere a totalidade, de fazer um estudo social no que lhe compete e não meramente atender a política institucional que é imposta.

Em Pernambuco, as entrevistadas afirmam ter encontrado pessoas que têm formação EaD e conseguem fazer uma análise crítica, que possuem um bom embasamento teórico. Contudo, como destacam, elas possuem uma formação anterior mais firme, seja uma formação básica de qualidade, uma formação superior anterior ou participação em movimentos sociais, ou seja, possuem esse lado crítico já vivenciado. "É diferente quando você tem um embasamento, por exemplo, o conjunto CFESS/CRESS já realizou formações à distância, mas eram cursos de especialização, entende-se que aquela pessoa já tem um embasamento, já tem uma base". (A.S. 2).

Portanto, o EaD sozinho não dá elementos suficientes para atuação profissional dos Assistentes Sociais dentro de uma totalidade, de uma formação crítica, propositiva, como deve ser o perfil desse profissional estabelecido pela ABEPSS. A formação dos profissionais direciona-se para prática, para técnica, secundarizando a problematização teórica e crítica. Trata-se de uma formação, 
portanto, que remete à pedagogia tecnicista (SAVIANI, 2012, p. 14), cujo objetivo principal é "[...] aprender a fazer".

Para o CFESS (2016), se o propósito dos cursos é a lucratividade e não a formação, esta última pode ser mantida em um patamar mínimo. Deste modo, as instituições privadas preocupam-se muito mais em beneficiar seu empresário do que garantir a qualidade da educação. Nesse contexto, as empresas educacionais diplomam seus estudantes com ênfase no treinamento, portanto, sem um trato teórico-metodológico rigoroso que a educação superior requer. Isso faz com que os egressos se tornem operadores práticos e não profissionais com capacidade crítica e propositiva.

É por isso que muitos dizem que não se faz mais Assistente Social como antigamente. E isso a gente encontra de tudo, se a gente for visitar os polos, as bibliotecas desses polos, pegar e folear os TCCs, você vê claramente, sem fazer análise mais profunda da precarização do ensino, no sentido da ortografia, da escrita. Erros gravíssimos, temos a dificuldade de entendimento. Aqui, a gente encontra muito no nosso atendimento, na reunião de novos inscritos, no nível da pergunta, no nível de colocações que esses profissionais estão tendo. Isso sem nenhum preconceito. (A.S. 2).

A própria lógica da reunião de novos inscritos realizada pelos profissionais do CRESS foi alterada, de modo a apresentar elementos que eles consideram essenciais para aqueles profissionais, mas que vinham mostrando-se flagrantemente ausentes durante as reuniões. São apresentados elementos básicos, que deveriam ser discutidos no início da formação, mas que, em decorrência da lacuna verificada, vêm sendo acrescidos nas reuniões, como por exemplo, a diferença entre Serviço Social, Assistente Social, a Política de Assistência Social e Serviços Sociais. Ademais, ao mencionar-se durante estes encontros aspectos referentes à bibliografia básica do curso, sente-se também uma ausência de conhecimento referente ao tema.

Eles não sabem quem é Marilda, não sabem quem é Netto. E quem faz o curso de Serviço Social sem saber quem é Marilda e quem é Netto, não fez Serviço Social. Porque o curso é passado com base 
na leitura desses dois livros que são básicos da formação. (A.S. 2).

São livros essenciais para formação7, considerados livros do próprio curso, mas que não vêm sendo disponibilizados para esses alunos, ou melhor, eles não vêm tendo acesso. De acordo com a A.S. 1: "São os pilares e eles não conhecem, inclusive assim, a gente tem uma parceria com a Cortez ${ }^{8}$, a gente nesse dia aproveita pra incentivar a leitura, disponibiliza aí material também, brochuras que são editadas pelo conjunto CFESS".

Quando você estuda numa universidade ou numa faculdade presencial você tem uma biblioteca, você tem contato com os livros, que isso é de suma importância, pois desde que o Serviço Social surgiu, foi institucionalizado, teve a sua primeira escola de Serviço Social em 1936 né? Vai fazer 80 anos que começamos a ter um primeiro contato com a leitura, que teve todo o processo de reformulação do Serviço Social e que veio com a entrada do Marxismo e que a gente fala que foi enviesado porque a gente não foi direto às fontes. É como se a gente tivesse revivendo isso porque eu vejo que essas pessoas não estão tendo acesso diretamente às fontes, porque a formação é feita através de vídeos- aula e de apostilas. Apostilas são coisas que as pessoas leram algo e sistematizaram naquele material. Então assim, não tem acesso diretamente à fonte, ao livro, a quem fala determinado assunto. (A.S. 2).

Para Netto (2011, p. 268-269), a aproximação inicial do Serviço Social com a tradição marxista, dadas as limitações da época, padece de diversos vícios, dentre eles a recorrência dos Assistentes Sociais a fontes secundárias, que de certo modo deformaram a compreensão de muitas das ideias marxianas. Conforme destaca, foram necessárias diversas e constantes revisões para que os profissionais avançassem em suas análises e constituíssem um arcabouço teórico-metodológico e político condizente com o proposto pela tradição marxista, abandonando as fontes secundárias e aprofundando elementos a partir da fonte original.

\footnotetext{
${ }^{7}$ Refere-se ao livro Ditadura e Serviço Social, de autoria de Netto (2011), e Relações Sociais e Serviço Social no Brasil, de lamamoto e Carvalho (2011).

${ }^{8}$ Refere-se à Livraria Cortez.
} 
Contudo, como podemos perceber na fala das agentes fiscais do CRESS-4 ${ }^{a}$ Região, nos cursos à distância de Serviço Social em Pernambuco, a ausência de bibliotecas e contato com os clássicos do curso apontam para um retrocesso profissional. Além das bibliotecas se configurarem como condição fundamental para funcionamento dos polos, como prevê as diretrizes do MEC (BRASIL, 2007), elas são essenciais também do ponto de vista da formação qualificada dos Assistentes Sociais.

São frequentes os problemas apontados pelas profissionais entrevistadas no que se refere ao material disponibilizado pelo EaD, pois o conteúdo além de tratar de sistematizações de obras, muitas vezes não condiz com a perspectiva do curso. "A concepção de Estado é totalmente distante da concepção de Estado que a gente estuda na formação [...]. Não é numa lógica de: a gente luta por uma nova ordem societária, é um Estado bonzinho" (A.S.2). Trata-se, pois, da formação de um profissional colaboracionista (PEREIRA, 2008), compatível com os interesses do capital.

Eu acho que se inicia pelo processo seletivo né? Como é esse processo seletivo no ensino à distância. E os trabalhos né? Não só o processo seletivo. Como é que eles avaliam esse aluno né? Que muitas vezes não é ele que faz o trabalho e encaminha. Eu tive uma experiência bem de perto, eu recebo uma amiga de São Paulo e ela tem uma escola de trânsito e pra ser diretora de uma escola de trânsito, dona, tem que ter formação superior e ela resolveu fazer Serviço Social à distância, só que quem tá fazendo o processo seletivo é a nora dela, que ficou em São Paulo e ela estava na minha casa, de férias, passeando, mas quem ia fazer a prova de seleção era a nora. Os trabalhos ela pagava pra alguém fazer, então, que formação é essa? Que exigência é essa? (A.S. 1).

Quanto à dinâmica pedagógica, a A.S. 2 ressalta que, ao ter contato e assistir a uma vídeoaula não-presencial, ficou inquieta, pois gostaria de perguntar, questionar o conteúdo presente no vídeo, mas não havia quem lhe respondesse. De igual modo, ela acredita que deve ocorrer com os alunos desta modalidade, sem possibilidades de questionamento, de perguntas, de respostas às suas dúvidas. 
Nesse sentido, apesar da importância das novas tecnologias para processos pedagógicos, inclusive em nível superior, estas não podem substituir a figura do professor ou o ambiente de convívio e troca de experiências coletivas presentes nas salas de aula convencionais. Logo, o uso das TIC deve ter por objetivo agregar possibilidades no processo de aprendizagem, mas não de substituição.

Seguindo este prisma, embora os cursos à distância apresentem possibilidades de inovação tecnológica e ampliação do acesso à educação superior, se olhado por outro ângulo, podem também se transformar em sistemas de franquias, que buscam adaptar a educação aos princípios de restaurantes fastfood, onde verdadeiras caixas negras são transmitidas sem nenhuma relação com a realidade social e cultural, e os alunos pagam e recebem esses pacotes passivamente (CRESS, 2009).

Pactuando do mesmo entendimento, as Assistentes Sociais ratificam a ideia de que a formação EaD fere os princípios da profissão, formando um profissional com perfil técnico, e que, portanto, não é compatível com uma graduação em Serviço Social. Para Pereira (2008), esta realidade brutal de mercantilização da formação profissional em Serviço Social, ao que tudo indica, atende aos interesses capitalistas e em pouco mais de uma década transformará totalmente o perfil profissional dos Assistentes Sociais. Esse perfil, segundo a autora, não é nada otimista, pois, baseado em uma formação à distância, aligeirada e mercantilizada, será incapaz de concretizar o perfil crítico e propositivo delineado pela ABEPSS.

b) O Cumprimento da Lei de estágio 11.788/2008, da Resolução CFESS 533/2008 e da Politica Nacional de Estágio da ABEPSS

Apesar de não se configurar como o problema mais recorrente na fala das entrevistadas, este é considerado pela categoria, no que pese os demais, a grande dificuldade desta modalidade de ensino. De qualquer modo, por relacionar-se fortemente às Diretrizes Curriculares, ao falar-se do Currículo aprovado pela ABEPSS, referese, em parte, ao momento do estágio curricular.

Segundo as Assistentes Sociais, ao verificar os materiais que são disponibilizados pelas instituições de ensino para o CRESS, é 
possível perceber que, na maioria deles, o estágio acontece em um mês, enquanto que a proposta estabelecida pela ABEPSS (1996) é de um estágio dividido em dois semestres e correspondente a $15 \%$ da carga horária do curso. Além disso, em detrimento das exigências da ABEPSS (2009), percebe-se desrespeito ao espaço do estágio quanto às condições éticas e técnicas do estágio, acompanhamento do estudante por um profissional de Serviço Social, elaboração de diário de campo etc. Nos termos da A.S. 1:

E a gente sempre bate na tecla da responsabilidade, que você tem de contribuir na formação desse aluno. Então essa quantidade, às vezes a pessoa tem dois vínculos, três estagiários em cada vínculo né? $\mathrm{E}$ aí a gente questiona a qualidade desse cumprimento da resolução 533, que trata sobre essa quantidade de alunos, mas que o estágio seja também um momento para refletir sobre essa formação, que é tão difícil no ensino à distância. (A.S. 1).

Deste modo, não se trata tão somente do cumprimento das leis e resoluções da profissão, mas de considerar as condições de realização com qualidade do processo de estágio, ou seja, que esse se estabeleça de fato, "[...] em uma atividade pedagógica constitutiva do processo de formação profissional” (ABEPSS, 2009, p. 34). Um exemplo apontado pelas profissionais refere-se a uma equipe de Assistentes Sociais, na qual cada um conta com três estagiários. Nesta situação, há um volume muito grande de estagiários na instituição e isso pode vir a prejudicar o atendimento ao usuário.

Outro exemplo mencionado faz alusão ao caso de supervisores que recebem um estagiário após o outro, sem reservar um momento de parada para avaliação de suas supervisões; além de profissionais que possuem uma demanda muito extensa e por este motivo necessitam realizar frequentes deslocamentos, prejudicando o momento da supervisão de estágio.

O estágio curricular deve ser pensado como um momento ímpar na formação do discente. Por esse motivo, necessita ser realizado em conformidade com as prerrogativas profissionais e em meio a condições éticas e técnicas. Precisa, pois, "ser um momento de você parar, orientar, supervisionar aquele estágio e não meramente assinar um documento". (A.S. 2). 
Outra questão que vem mobilizando o CRESS e que está em estudo, podendo culminar em uma resolução do CFESS, é a realidade de profissionais como supervisores de campo não inscritos no CRESS de jurisdição do campo de estágio. São situações bastante recorrentes, que vêm apresentando desafios ao processo de fiscalização.

[...] isso não rebate somente na fiscalização, rebate nos outros setores aqui, porque ultimamente a gente tem feito isso [...] de tá enviando para o financeiro e para o setor de inscrição essa relação que vem pra gente, pra saber se esses profissionais estão legalmente inscritos, se eles estão regularmente em dia com a anuidade do CRESS. O 'mínimo' que a gente consegue fazer é identificar a situação desses profissionais que estão espalhados pelos campos de estágio. (A.S. 1).

Além desses desafios, foram recorrentemente mencionados pelas entrevistadas problemas referentes à ausência de supervisão acadêmica, assédio e pressão sofrida pelos Assistentes Sociais para abertura de campos de estágio, responsabilização da abertura de campo de estágio submetida ao estudante, supervisores de campo e acadêmico em exercício irregular da profissão, número insuficiente de supervisores em detrimento ao de alunos em momento de estágio, supervisor de campo com número excessivo de estagiários em relação à carga horária de trabalho etc..

Segundo o CFESS (2014, p. 25), na modalidade de EaD, “[...] a realização da supervisão direta de estágio qualificada tornase claramente um 'entrave' para a lógica massificada de tal modalidade de ensino, especialmente se considerarmos os polos de EaD localizados no interior [...]", que contam com poucos Assistentes Sociais inseridos em prováveis instituições campos de estágio. Ademais, de acordo com a ABEPSS (2009):

O estágio supervisionado curricular, além dos aspectos pedagógicos relacionados diretamente às disciplinas, implica, ainda, a ampliação de estratégias que viabilizem a oferta e qualificação de campos aos estudantes, que se alteram profundamente mediante o crescimento do número de escolas e de estudantes de Serviço Social. Estas mudanças, já apontadas na 
contextualização da Universidade, trouxeram à tona, nos debates regionais, um dos cenários lamentáveis ocasionado pela contrarreforma. As denúncias descreveram as disputas por vagas de estágio em troca de material de consumo e outras formas de clientelismo, que são acirradas de maneira perversa em algumas Unidades presenciais e com maior ênfase nas unidades não presenciais, na busca por novos campos para atender a demanda da abertura inconsequente de vagas nos cursos de Serviço Social nesses últimos anos (ABEPSS, 2009, p. 34).

Este problema é bastante recorrente na realidade pernambucana e, como pudemos observar, esteve muito presente na fala das Assistentes Sociais do CRESS $4{ }^{\text {a }}$ Região, visto que reflete fortemente a expansão desmesurada do ensino à distância. Trata-se, pois, da corrida pelo lucro e pela obtenção de um grande número de matrículas, sem considerar as condições em que será desenvolvida essa formação e as possibilidades de encontrar campo de estágio para os discentes.

A demanda é tão grande que às vezes naquele município não tem campo de Estágio. Toda vez a gente cita o exemplo de Fernando de Noronha, que implantou o curso de Serviço Social lá à distância e tinha 64 alunos e só tinha 5 profissionais de Serviço Social na ilha. Então quando chegou a época de estágio eles convocaram o CRESS, para gente resolver, indicar alguma saída. Então assim, é um volume muito grande, a gente sabe, alguns boatos, alguns relatos na verdade, [...] que em Garanhuns agora tem 700 alunos esperando campos de estágio. Terminou o curso e ainda ficou faltando o estágio, esperando concluir né? Para colar grau. (A.S. 1).

São problemas, como os ressaltados, muito frequentes em municípios de pequeno e médio porte, onde são implantados polos com oferta de curso em Serviço Social sem consideração acerca da possibilidade de campos de estágio para todos os alunos. Ainda em entrevista, a A.S. 2 destacou o caso de um município onde foi realizar um processo de fiscalização. Segundo ela, a cidade por ser de pequeno porte, deixava clara a dificuldade que aquela unidade de ensino iria encontrar no processo de estágio. Diante disso, a profissional resolveu conversar com o coordenador do polo, 
contudo, ao tentar demonstrar as dificuldades para cumprimento do estágio pelos discentes, a resposta do profissional foi: "Logo Serviço Social, o curso que tem mais matrículas?” Ou seja, capital. O interesse é realmente esse.

Deste modo, como pôde ser observado, o momento do estágio supervisionado vem sendo tratado em tais cursos, apesar de sua importância ímpar no processo de aprendizagem do discente, sem condições efetivas de garantia da qualidade na formação e problematização teórico-metodológica dos alunos referente ao espaço sócio-ocupacional do Assistente Social.

\section{c) Perfil da tutoria em consonância com os instrumentos regulatórios do exercício e formação profissional}

Muito frequentes também foram os relatos das entrevistadas referentes ao descumprimento do Artigo $5^{\circ}$ da Lei de Regulamentação da Profissão, que estabelece as atribuições privatistas do Assistente Social. São diversas as irregularidades presentes no estado de Pernambuco referente à temática: coordenações do curso exercidas por profissionais de outras áreas; tutores que não possuem formação em Serviço Social; tutores que possuem a formação em Serviço Social, mas não tem o registro no CRESS; tutores que se encontram com o registro cancelado e tutores que possuem o registro de outra jurisdição, mas encontramse atuando em Pernambuco.

Além dos elementos supracitados, segundo as entrevistadas, fato preocupante é grande parte de estes profissionais afirmarem gostar do exercício de tutoria por acreditar que é uma forma de se capacitarem, de rever o conteúdo da formação. Para exercer o papel de magistério em Serviço Social é fundamental um profissional preparado para ministrar aulas, com mestrado e doutorado. Esse profissional não deve acompanhar e procurar atualizar-se com o conteúdo de sala, como vem acontecendo com as tutorias.

Vale ressaltar também que essas empresas educacionais, por meio do EaD, garantem muitas matrículas sem, no entanto, necessitar da contratação de tantos docentes, substituídos pela contratação de diversos tutores, que geralmente possuem vínculos trabalhistas precários e baixos salários. Portanto, para além da mudança 
no papel do professor, é preciso considerar os impactos desta modalidade nas relações de trabalho, pois este novo profissional da educação, em sua imensa maioria, além dos baixos salários, não dispõe dos direitos tradicionais como férias e carteira assinada.

O Serviço Social brasileiro se consolida em seus 80 anos como profissão combativa, que construiu um projeto profissional identificado com um novo modelo societário e em favor dos interesses da classe trabalhadora (CFESS, 2016). Portanto, para além das questões atinentes à formação profissional mercantil e à distância em Serviço Social, a profissão reforça seu compromisso e ações políticas contra qualquer forma de precarização do trabalho.

Quando identificado alguns dos problemas que representem infração legal, o CRESS- $4^{\text {a }}$ Região encaminha a problemática para a assessoria jurídica, para que esta tome as medidas cabíveis. 0 Conselho Regional também encaminha as informações para o CFESS, através de relatório e dossiê, para que este recolha todas as irregularidades do Brasil e encaminhe para o Ministério da Educação, para que este último, enquanto órgão responsável pela fiscalização e controle da educação nacional, tome as medidas necessárias. Foi por meio destas informações e encaminhamentos que algumas instituições foram proibidas de ofertar cursos de Serviço Social, apresentando resultados parciais da luta da categoria contra a precarização do ensino do EaD.

\section{d) Posicionamento dos Conselhos frente ao EaD}

Embora o Conjunto CFESS-CRESS realize diversos esforços políticos e acadêmicos no sentido de demonstrar que o questionamento do uso da modalidade de EaD para a formação de graduação em Serviço Social não é discriminatória, mas objetiva alertar para o aprofundamento da precarização do ensino superior no país e a negação do direito à uma educação qualidade e universal, são diversas as afirmativas de que os conselhos se posicionam de forma preconceituosa em relação a estes profissionais e estudantes. Portanto, como não poderia deixar de ser, esta também é uma temática apresentada nas entrevistas.

Conforme ressalta a A.S. 2, já existe, no Rio Grande do Sul, uma lei estadual que proíbe qualquer tipo de discriminação contra alunos 
de ensino à distância. Além disto, existem diversas denúncias, em alguns estados, de pessoas que se julgam discriminadas. Em Pernambuco, embora não exista nenhuma denúncia voltada ao conselho, existem acusações contra Assistentes Sociais e contra instituições, pois, como ressalta, são frequentes os casos de instituições que abrem vagas para estágio e declaram não aceitar estudantes do EaD ou profissionais que também se recusam a supervisionar alunos da modalidade à distância.

As entrevistadas destacam que, dentro desta realidade, embora se posicionem contra esta modalidade de ensino, fazem-no de modo muito cuidadoso, para que sua postura não seja entendida como alguma forma de discriminação.

Apesar de em uma única vez ter percebido uma interpretação preconceituosa de sua atitude, a A.S 2 acredita que, nas reuniões de novos inscritos, muitos dos alunos advindos do EaD devem possuir este entendimento de preconceito relativo aos conselhos, contudo, não há uma denúncia formalizada. A profissional explica que o comentário de que ela havia agido de forma preconceituosa surgiu certa vez quando foi falar sobre elaboração de laudos e pareceres com uma Assistente Social. Em suas palavras: "a gente encontrou uma situação de elaboração de laudos e pareceres em conjunto, a gente foi explicar como é a elaboração de laudos e pareceres, que não é em conjunto, que é terminantemente proibido e a pessoa se sentiu discriminada". Coincidência ou não, tratava-se de um município onde a grande maioria dos profissionais era oriunda do ensino à distância e somente dois não eram.

Assim, discriminar depende da forma que ela se coloca. Mas não aceitar o que vai de encontro aos seus princípios não é discriminar. Por exemplo, aqui no CRESS a nossa luta, a nossa bandeira de luta é contra o ensino à distância, a gente não aceitar um aluno à distância como estagiário, isso eu não vejo como um preconceito, está dentro da lógica do que a gente prega. Por exemplo, eu respondi a um polo de EaD que veio denunciar a ABEPSS por não ter aceito a inscrição dele. Eu disse: "a ABEPSS é uma instituição brasileira de ensino e pesquisa em Serviço Social, a sua instituição tem ensino?" "Tem". "Tem pesquisa?" "Não." "Então não é preconceito". São 
princípios, são lógicas que você defende e se você não está dentro daquela lógica, você não está dentro daquela instituição. Agora a lógica "eu não quero porque você é EaD” aí sim já é diferente entendeu? Já é diferente! (A.S. 2).

O mesmo entendimento é ressaltado pelo CFESS (2014), que explicita o seu posicionamento contra o ensino à distância, sem que isso venha a resultar em uma culpabilização ou discriminação dos diversos sujeitos inseridos no processo de formação EaD. Isto é, a entidade destaca que seu princípio volta-se em favor de uma educação pública, de qualidade e gratuita, portanto, que sua crítica direciona-se à lógica de mercantilização do ensino superior brasileiro, bem como à precarização da formação e desvalorização profissional dos Assistentes Sociais.

\section{e) 'Democratização do acesso' e aumento do contingente profissional}

Embora se refira a um processo iniciado no governo Fernando Henrique, na gestão de Luiz Inácio Lula da Silva, a expansão do ensino superior foi tratada dentro de uma configuração discursiva que enuncia claramente o tema da democratização do acesso e justiça social. Não se trata tão somente de ampliar o acesso e expandir o sistema, conforme destaca Gomes (2008). No governo Lula, tal questão vem acompanhada da incorporação de setores historicamente excluídos deste nível de ensino. Nos termos do autor:

Fundado no conceito de redistribuição de renda, no sentido de que a expansão da educação superior passa necessariamente pela incorporação de setores tradicionalmente excluídos da educação superior: a população estudantil de baixa renda proveniente das escolas públicas, no que se inclui a população negra e grupos étnico-raciais. Esse recorte das políticas de expansão, ausente nas políticas governamentais de nossa história, é constitutivo de uma outra formação discursiva, dirigida ao setor privado, como atesta o ProUni [Programa Universidade para Todos], quanto ao setor público, como testemunham as iniciativas de políticas de cota, de criação de novas universidades, de interiorização da educação superior pública através da criação de campi universitários em cidades de médio porte, e como também está claro no REUNI 
[Programa de Apoio a Planos de Reestruturação e Expansão das Universidades Federais] e no Projeto de Lei sobre a Reforma da Educação Superior (GOMES, 2008, p. 30).

Neste contexto de democratização e ampliação das vagas, verifica-se, na gestão petista uma supervalorização do EaD no processo de 'democratização' do acesso à educação superior. Trata-se de uma expansão, todavia, que não vem preservando a qualidade da formação e respeitando os princípios profissionais dos Assistentes Sociais.

É mais que compreensível que as pessoas que não estavam tendo acesso. Elas estão tendo essa oportunidade, mas aí volto a dizer: que oportunidade é essa? A gente não é contra que as pessoas tenham oportunidade do ensino né? A gente é a favor que esse ensino seja de qualidade e que não fira os princípios da nossa profissão, porque o ensino EaD é incompatível com o Serviço Social, porque ele não dá elementos suficientes para a nossa atuação enquanto Assistentes Sociais, dentro da totalidade, da formação crítica, propositiva, como é o perfil do profissional [...]. (A.S. 2).

Trata-se de um processo expansivo que tem impactado fortemente as entidades da categoria, com uma demanda cada vez mais extensa de alunos oriundos destas instituições solicitando inscrição no conselho. Como destacam as Assistentes Sociais entrevistadas, aumenta cada vez mais também o número de profissionais e de campos de estágio para fiscalizar. O estado de Pernambuco conta atualmente com aproximadamente 6.000 Assistentes Sociais com inscrição aberta no CRESS para apenas duas agentes fiscais. $O$ mais preocupante é que esse número de graduados e demanda de inscrição não para de crescer, tudo sob o discurso democrático e sem qualidade.

"Em 2011, era uma reunião mensal com novos inscritos, em torno de trinta novos inscritos mensalmente. Isso foi aumentando, chegando a ter que ser duas reuniões mensais e, ultimamente, tem tido recorrência muito de três reuniões mensais" (A.S. 2). No meio e final do ano, esse quadro torna-se ainda mais agravante, pois se formam também alunos das instituições presenciais, contudo, 
como se destacou, o quantitativo do EaD além de mensal, sempre supera o das presenciais.

A A.S. 1 menciona o exemplo de uma visita de fiscalização que realizou em um CREAS do município de Olinda e, ao falar com a Assistente Social do local, esta explicou que havia participado da reunião de novos inscritos há pouco tempo e era a única profissional formada em instituição de ensino presencial na reunião, sentindose constrangida diante das demais pessoas e com vergonha de dizer que era formada em uma instituição presencial.

E isso não é uma realidade de Pernambuco não, é de todos os estados. A gente tem uma realidade que está respingando em Pernambuco, é o caso da Bahia. Bahia faz divisa com Pernambuco, Petrolina, Juazeiro. A Bahia, segundo informações das agentes fiscais de lá, é uma média de 100 mensais de novos inscritos, aí o que é que tá acontecendo, atrasa um pouco a inscrição desses profissionais, né? Lá a demanda é muito grande. Aí o que é que os profissionais de juazeiro estão fazendo... Estão vindo para Pernambuco para se inscrever e isso pode acarretar exercício ilegal da profissão porque ele se inscreve em Pernambuco e pode vim a utilizar sua inscrição de Pernambuco na Bahia e isso é exercício ilegal, porque você não pode usar seu registro numa jurisdição que você não é vinculado, entendeu? Aí, às vezes, eles fazem: "ah não, porque o processo de transferência é mais rápido do que o de primeira inscrição". Porque pra se inscrever você tem que se inscrever, passa o período de análise da Comissão de inscrição do documento, depois agenda uma reunião, que é a reunião de novos inscritos e como a demanda lá é grande, isso chega a demorar, aí eles querem logo o registro e vêm para Pernambuco se inscrever. (A.S. 2).

Para lamamoto (2009), o crescimento do contingente profissional, ainda que reflita a expansão do mercado de trabalho especializado, poderá desdobrar-se na criação de um exército assistencial de reserva. Isto é, uma saída para qualificação de um voluntariado no apoio à solidariedade em um ambiente político que estimula a criminalização da questão social e das lutas sociais e o caráter assistencial das políticas públicas. Ainda segundo 
a autora, a massificação e a perda de qualidade da formação universitária estimulam o reforço de estruturas ideológicas que facilitam a subordinação dos profissionais às ‘normas do mercado', resultando em um processo de despolitização da categoria.

Às vezes eu tenho a sensação de que Zé Paulo Netto é o guru do Serviço Social, que ele tem uma bola de cristal e vê além do hoje né? Porque me lembro de um texto que eu li dele, não estou lembrada qual foi especificamente, que ele fala que existe o cadastro de reserva e existe o cadastro assistencial de reserva, e eu vejo essa realidade hoje, porque a partir do momento que tem muitos profissionais aí sendo jogados no mercado de trabalho, isso faz com que o nosso salário também diminua porque existe uma demanda extensa, tem Assistente Social para quem quiser. Exército assistencial de reserva, porque são muitos Assistentes Sociais aí lutando por uma vaga no mercado de trabalho né? E quando essa demanda é grande, o salário também baixa, e as condições desse trabalho também [...]. (A.S. 2).

Como ressaltado pelo CFESS Manifesta (CFESS, 2012), esta realidade de massificação do ensino impacta na formação profissional, sobretudo dos novos Assistentes Sociais, egressos do $\mathrm{EaD}$, pois a graduação nesta modalidade fere princípios e diretrizes defendidos pelas Diretrizes Curriculares da ABEPSS, o que trará modificações para o mercado de trabalho em Serviço Social, bem como enormes desafios para defesa do projeto profissional. Mas acima de tudo, trata-se de retirar da juventude o acesso real à educação e ao conhecimento, e dos nossos usuários, a possibilidade concreta de ter um atendimento profissional qualificado.

Esse discurso de democratização do acesso no EaD acaba sendo reforçado mediante o processo seletivo dos alunos, pelo baixo custo das mensalidades e diversos programas de apoio educacional, como FIES e ProUni. Esse movimento leva a população historicamente excluída do ensino superior a se sentir contemplada nesta modalidade de ensino.

É racionalizar o irracionalismo do capitalismo. É essa a lógica que o ensino hoje coloca. Para você 
não ver que você está sendo explorado né? É uma falsa democracia de acesso [...]. Mas que tipo de educação e formação eu estou tendo? A alienação está sendo cada vez mais presente na sociedade como um todo. (A.S. 2).

Neste contexto, como defendido por Pereira (2008), em um processo dialético, o ensino superior, ao mesmo tempo em que é configurado na nova conjuntura em crise do capitalismo como espaço mercantilizado, é ele próprio um elemento fundamental para difusão ideológica burguesa, mediante a formação em massa de intelectuais colaboracionistas à ordem do capital. As reformas educacionais surgem, portanto, como meio de captação das subjetividades da população, com base no discurso da inclusão, acesso à capacitação e passaporte para a empregabilidade, desconsiderando a emissão em massa de certificados e a incapacidade do mercado de trabalho em absorver esse grande número de profissionais.

\section{CONSIDERAÇÕES FINAIS}

Este trabalho objetivou apresentar elementos acerca da expansão da modalidade de ensino à distância em Serviço Social e suas implicações para a formação dos Assistentes Sociais, tendo como base de nossa análise a realidade pernambucana. A partir da análise realizada, apreende-se que os cursos EaD em Serviço Social proliferam-se no mesmo ritmo expansionista, mercantilista e sem qualidade do ensino superior brasileiro, com ênfase nos interesses dos grandes grupos empresariais no curso em questão.

O resultado do levantamento de informações identificadas pelo CRESS $-4^{\text {a }}$ Região em seu processo de fiscalização corrobora essa posição, uma vez que revelam diversos fatores que colidem com a garantia de uma educação superior de qualidade, em consonância com os princípios da profissão. Verificamos, portanto, através dos dados, a existência de diversas problemáticas presentes nos cursos de Serviço Social desenvolvidos na modalidade à distância no estado de Pernambuco e que podem impactar negativamente a formação profissional dos Assistentes Sociais.

Verificamos a desqualificação do processo formativo, confirmada pelas condições inadequadas nas quais são realizados os estágios 
supervisionados, escasso acesso à bibliografia básica do curso, inexistência de bibliotecas nos polos, ausência de vivência acadêmica dos alunos, falta de convivência com diferentes docentes e discentes, condições precárias de funcionamento dos polos, ausência de atividades de pesquisa e extensão nas unidades de ensino, condições trabalhistas precárias dos tutores, assédio aos profissionais em campo pelas instituições em relação ao recebimento de estagiários, tutores em exercício irregular da profissão, etc.

Consideramos que as situações expostas não se configuram como acasos, mas representam o modelo de expansão da educação superior brasileira na contemporaneidade: massificada, mercantil e sem garantia da devida qualidade. Um processo formativo que poderá refletir-se em uma reconfiguração do perfil dos Assistentes Sociais brasileiros e desvalorização de seu trabalho profissional.

\section{REFERÊNCIAS}

ABEPSS. Diretrizes Gerais para o curso de Serviço Social. Rio de Janeiro, 1996.

ABEPSS. Política Nacional de Estágio da Associação Brasileira de Ensino e Pesquisa em Serviço Social - ABEPSS. Rio de Janeiro, 2009. Disponível em: <http://www.cfess.org.br/arquivos/ pneabepss_maio2010_corrigida.pdf>. Acesso em: 4 maio 2016.

ANDERSON, Perry. Balanço do neoliberalismo. In: PÓSNEOLIBERALISMO: as políticas Sociais e o Estado Democrático. Rio de Janeiro: Paz e Terra: 1995.

BRASIL. Ministério da Educação. Censo da Educação Superior de 2009. Brasília (DF), 2010.

BRASIL. Ministério da Educação. e-MEC. Insitutições de educação superior e cursos cadastrados. Brasília (DF): c2017. Disponível em: <http://emec.mec.gov.br/>. Acesso em: 22 jun. 2017.

BRASIL. Ministério da Educação. Referenciais de qualidade para Educação Superior à Distância. Brasília (DF), 2007. Disponível em: <http://portal.mec.gov.br/seed/arquivos/pdf/legislacao/refead1. pdf> . Acesso em: 4 maio 2016.

CHAUÍ, Marilena. Escritos sobre a universidade. São Paulo: UNESP, 2001. 
CFESS. CFESS Manifesta: Educação não é fast-food: diga não para a graduação à distância em Serviço Social. Brasília (DF), $2011 a$.

CFESS. CFESS Manifesta. Temporalis, Brasilia (DF), ano 11, n. 21, p. 281-288, jan./jun. 2011b.

CFESS. CFESS Manifesta: Dia do/a Assistente social. Brasília (DF), maio 2012.

CFESS. Sobre a incompatibilidade de graduação à distância e Serviço Social. Brasília (DF): 2014. v. 2.

CFESS. CFESS Manifesta: Assistentes Sociais por uma educação pública e de qualidade. Brasília (DF), 2016.

CRESS. Ensino à Distância em Serviço Social no Espírito Santo. Vitória: CRESS $17^{\mathrm{a}}$ Região/ES, 2009.

GOMES, Marcelo Alfredo. As reformas e políticas da educação superior no Brasil: avanços e recuos. In: MANCEBO, Dirse et al. (Org.). Reformas e políticas: educação superior e pós-graduação no brasil. São Paulo: Alínea, 2008.

GOOGLE MAPS. Pernambuco. c2017. Disponível em: <https:// www.google.com.br/maps/place/Pernambuco/@-6.6516096,39.1202749,7z/data=!3m1!4b1!4m5!3m4!1s0x7007c9d931c86c5:0 x1de0196a93401726!8m2!3d-8.8137173!4d-36.954107?hl=pt-BR>. Acesso em: 22 jun. 2017.

IAMAMOTO, Marilda Villela; CARVALHO, Raul. Relações Sociais e Serviço Social no Brasil: Esboço de uma interpretação históricometodológica. 34. ed. São Paulo: Cortez, 2011.

IAMAMOTO, Marilda Villela. O Serviço Social na cena contemporânea. In: CFESS/ABEPSS. Serviço Social: Direitos Sociais e Competências Profissionais. Brasília: CFESS/ABEPSS, 2009.

IBGE. Censo Demográfico 2010: Características da População e dos Domicílios: Resultados do Universo. Brasília (DF), 2010 a. Disponível em: <http://www.ibge.gov.br/estadosat/temas.php?sig|

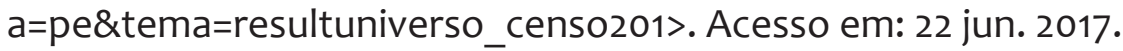

IBGE. Estad@s: Pernambuco: Síntese. Brasília (DF), $2010 b$. Disponível em: <http://www.ibge.gov.br/estadosat/perfil. php?sigla=pe>. Acesso em: 22 jun. 2017. 
INSTITUTO NACIONAL DE ESTUDOS E PESQUISAS EDUCACIONAIS ANÍSIO TEIXEIRA (Brasil). Sinopse da educação superior 2009. Brasília (DF), 2009. Disponível em: <http://inep.gov.br/sinopsesestatisticas-da-educacao-superior>. Acesso em: 18 jun. 2017. LIMA, Kátia Regina de Souza. Contra-reforma na educação superior: de FHC a Lula. São Paulo: Xamã, 2007.

MINAYO, Maria Cecília de Souza. O desafio do conhecimento: pesquisa qualitativa em saúde. 12. ed. São Paulo: Hucitec, 2010. NETTO, José Paulo. Ditadura e Serviço Social: uma análise do Serviço Social no Brasil pós-64. 16. ed. São Paulo: Cortez, 2011. SAVIANI, Dermeval. Escola e Democracia. 42. ed. São Paulo: Autores Associados, 2012.

SINDICATO DAS MANTENEDORAS DE ENSINO SUPERIOR (São Paulo). Mapa do Ensino Superior no Brasil 2016. São Paulo, 2016. Disponível em: <http://convergenciacom.net/pdf/mapa_ensino_ superior_2016.pdf>. Acesso em: 17 jul. 2017.

SETÚBAL, Aglair Alencar. Análise de Conteúdo: suas implicações nos estudos das comunicações. In. MARTINELLI, Maria Lúcia. Pesquisa qualitativa: um instigante desafio. São Paulo: Veras, 1999.

SOARES, Laura Tavares. Os custos do ajuste neoliberal na América Latina. 3. ed. São Paulo: Cortez, 2009.

PEREIRA, Larissa Dahmer. Educação e Serviço Social: do confessionalismo ao empresariamento da formação profissional. São Paulo: Xamã, 2008.

PEREIRA, Larissa Dahmer. Mercantilização do ensino superior, educação à distância e Serviço Social. Rev. Katál. Florianópolis, v. 12, n. 2, p. 268-277, jul./dez. 2009. 